\title{
Influence of Communication and Teaching Lecturers Competencies Towards Students Online Learning Satisfaction in the Time of Covid-19
}

\author{
Betty Leindarita* \\ Sekolah Tinggi Ilmu Ekonomi (STIE) Pembangunan Tanjungpinang, Indonesia \\ *Corresponding author. Email: betty.leindarita@yahoo.co.id
}

\begin{abstract}
The purpose of this study was to analyze the effect of communication and the competence of teaching lecturers on student online learning satisfaction during the Covid-19 period. Type of associative research study was used to search for a correlation causal relationship. As many as 613 samples and 242 respondents were treated in this research. Methods of analysis used multiple linear analyses. The test results show learning satisfaction among STIE students of Tanjungpinang with multiple linear regression method $\mathrm{Y}=12.468+0.199 \mathrm{X} 1+0.271 \mathrm{X} 2+\mathrm{e}$ with regression coefficient value communication variable $(\mathrm{X} 1)=0.199$, competency variable regression coefficient value $(\mathrm{X} 2)=$ 0.271 . The results of $t$ test obtained a communication variable $(X 1) t$ count $>t$ table $(3.344>1.969)$. Competency variable $(X 2)$ result was $t$ count $>t$ table $(4.273>1.969)$. The results showed that the communication and competency variables simultaneously had a positive and significant effect on the learning satisfaction of STIE Pembangunan Tanjungpinang students, with a contribution of adjusted $\mathrm{R}^{2}$ of 0.391 or $39.1 \%$. This means that the communication and competency variables together have an influence on learning satisfaction by $39.1 \%$. The remaining $60.9 \%$ is influenced by other factors.
\end{abstract}

Keywords: Communication, Competence, Satisfaction.

\section{INTRODUCTION}

The Covid-19 pandemic that has swept across the world has forced the government to make various new policies to break the chain of spreading the Covid-19 virus. One of the policies that have been taken by the government is the application of physical distancing or maintaining physical distance between individuals. The physical distancing policy causes face-to-face learning activities at all levels of education cannot be implemented. Education providers must take policies related to the implementation of learning activities so that learning outcomes can be achieved. With the physical distancing policy, the ministry of education and culture issued a policy of home learning using online learning. Online learning is an option because of its flexible nature, which allows students to access information and learning resources without time and space boundaries. Online learning is the best choice for continuing to carry out lectures [1].
Online learning emphasizes students to process information presented by lecturers online. Online learning has the same meaning as e-learning [1]. In a narrow sense, e-learning can be defined as any learning activity that occurs via the Internet [2]. Previous study shows that e-learning is effective for students regardless of student background [3]. E-learning is the future of education because of its interactive, engaging and entertaining way of learning, and will soon replace paper books in the form of touch screen tablets [4]. Elearning facilitates learners to take control over content, manage learning sequences, determine learning speed, improve time and select media to meet their learning goals as well as to manage access to e-learning methods and materials [5]. In e-learning students will be required to play an active role during the learning process; student activity during the learning process will be able to improve student learning outcomes [6].

Student satisfaction in undergoing this distance and online learning $(\mathrm{PJJ})$ is an important input in order to improve in the future. The role of information and 
communication technology literacy is important in PJJ during the Covid-19 pandemic [7]. Especially if the Covid-19 pandemic still occurs, PJJ will continue to be chosen as the safest method, especially in the City of Tanjungpinang where the location of the university is which is currently in the red zone. This research can contribute in providing input regarding the current implementation of PJJ. Therefore, the purpose of this study is to determine the impact of the Covid-19 pandemic on distance learning satisfaction.

The phenomenon of the satisfaction variable during the Covid 19 pandemic is distinguished on two sides. Based on the pre-interview results of 10 STIE Pembangunan students, it can be seen that the majority of students are dissatisfied with current distance learning. The impact of Covid-19 turned out to be a lot of dissatisfaction with students in receiving learning materials. This is for many reasons. The main reason is because so far students have received face-to-face learning, resulting in mental unpreparedness in using various distance learning / PJJ methods. The second reason is, signal disruption and high internet quota, so the explanation given is not optimal. Besides that, the workload given by the lecturer every day is too much. And more do not understand the subject matter which must be understood by themselves rather than face to face. On the lecturer side, it turns out that many lecturers have less potential in teaching material online, and do not understand technology.

The problem with online learning is the habitual pattern of teaching and learning methods for students and lecturers who are accustomed to conventional learning. Lecturers are still not used to teaching using complex online media that must be packaged effectively, easily accessible and understood by students. Meanwhile, students really need a culture of independent learning and the habit of learning to follow computers or gadgets. Lecturers are required to be able to design or design light and effective online learning, by utilizing the right online tools or media and in accordance with the material being taught.

Communication is the exchange of information between senders and receivers, and draws conclusions as perceptions of the meaning of something between the individuals involved. It is also said to be an interpersonal exchange of information [8]. The phenomenon of variable communication that occurs here, for example in online learning, often occurs technical disturbances such as unstable signal networks, as a result the delivery of knowledge information is imperfect, even often losing contact and leaving online groups by itself. It often happens when online learning is in progress, internet quota pulses suddenly run out, and it takes quite a long time to buy credit and rejoin online media. Communication like this is very ineffective and more costly than face-to-face, so the expected communication does not go well and optimally.

Competence is a basic characteristic of an individual which is causally related to a reference measure of active or high performance and a job or situation [9]. The phenomenon of competence is that there are still many unskilled lecturers in using laptop devices and using the internet network online. Lack of mastery of competence in the IT sector and everything online during the Covid 19 period, made lecturers provide material as it is and not maximally, some even just gave assignments without explaining the subject matter. So that students do not understand what is being said.

Seeing the above phenomenon, researchers are interested in making research with the title Analysis of the Effect of Communication and Lecturer Competence on Student Online Learning Satisfaction during the COVID-19 Pandemic (Case Study of STIE Pembangunan Tanjungpinang Students).

\subsection{Problem Formulation}

The first formulation in this study is Does communication affect students' online learning satisfaction during the COVID-19 pandemic? As for the second formula, Does the competence of Lecturers affect Student Online Learning Satisfaction during the COVID-19 Pandemic? Likewise for the third problem formulation, Does the Communication and Competence of Lecturers have a joint effect on Student Online Learning Satisfaction during the COVID-19 Pandemic?

\subsection{Research Objectives}

The purpose of this research is to conduct a study on the influence of communication and the competence of lecturers on Student Online Learning Satisfaction during the COVID-19 Pandemic. The purpose of this study specifically is to determine: First, the effect of communication on Student Online Learning Satisfaction. Second, the influence of Lecturer competence on the Student Online Learning Satisfaction was monitored, and the third is the influence of the Communication and Lecturer Competence variables together on Student Online Learning Satisfaction during the COVID-19 Pandemic.

\section{REVIEW OF THEORY}

The Covid-19 pandemic that has swept across the world has forced the government to make various new policies to break the chain of spreading the Covid-19 
virus. One of the policies that have been taken by the government is the application of physical distancing or maintaining physical distance between individuals. The physical distancing policy causes face-to-face learning activities at all levels of education cannot be implemented. Education providers must take policies related to the implementation of learning activities so that learning outcomes

\subsection{Communication}

Communication is the process by which information or meaning is transferred from sender to receiver. This communication has several indicators, namely: understanding, pleasure, influence on attitudes, and better relationships [10].

\subsection{Competence}

Competence is in general the definition of competence is the level of skills, knowledge, and behavior possessed by an individual in carrying out the tasks assigned to him in the organization. This competency has several indicators, namely: personal traits, skills, and knowledge [10].

\subsection{Learning Satisfaction}

Learning satisfaction is defined as the perception of the benefits (usefulness) is fun (enjoyed) and helps (helpful) in understanding something that is interpreted by individuals in the learning process. The indicators of learning satisfaction are as follows: facilities and infrastructure, professional teaching competence, and administrative services [10].

\section{RESEARCH METHODS}

The location used in this research is STIE Pembangunan Tanjungpinang which is located at Jalan Raja Hajj Fisabillilah Number 34 Tanjungpinang, Riau Islands. The population in this study was students of STIE Pembangunan Tanjungpinang, active students who were undergoing PJJ majoring in management and acconting for the period 2019/2020. Respondents were selected randomly, from various semesters. The number of respondents in this study was 242 people. The data collection method was carried out by distributing electronic questionnaires. The distribution of electronic questionnaires was carried out through Whatsapp social media to class groups at STIE Pembangunan Tanjungpinang. The distribution and collection of primary data took place in approximately 1 month during the Covid-19 pandemic.

\section{RESULTS AND DISCUSSION}

This research produces important points related to the impact of the Covid-19 pandemic on PJJ satisfaction among students, especially STIE Pembangunan Tanjungpinang students. The results of the research are presented starting from the characteristics of the informants to discussion based on the relevant literature with various aspects studied. The details are as follows:

Table 1. Informant Characteristics

\begin{tabular}{|l|l|c|c|}
\hline \multicolumn{2}{|c|}{ Informant Characteristics } & Frequency & Percent \\
\hline \multirow{4}{*}{ Gender } & Male & 68 & $28,1 \%$ \\
\cline { 2 - 4 } & Female & 174 & $71,9 \%$ \\
\cline { 2 - 4 } & Total & 242 & $100,0 \%$ \\
\cline { 2 - 4 } & Management & 141 & $58,2 \%$ \\
\hline \multirow{5}{*}{ Study program } & Accounting & 101 & $41,8 \%$ \\
\cline { 2 - 4 } & Total & 242 & $100,0 \%$ \\
\cline { 2 - 4 } & 1 & 9 & $3,7 \%$ \\
\cline { 2 - 4 } & 3 & 60 & $24,8 \%$ \\
\hline \multirow{5}{*}{ Semester } & 5 & 170 & $70,2 \%$ \\
\cline { 2 - 4 } & 7 & 3 & $1,2 \%$ \\
\cline { 2 - 4 } & Total & 242 & $100 \%$ \\
\hline
\end{tabular}

\section{Respondents Majoring In Manajemen}

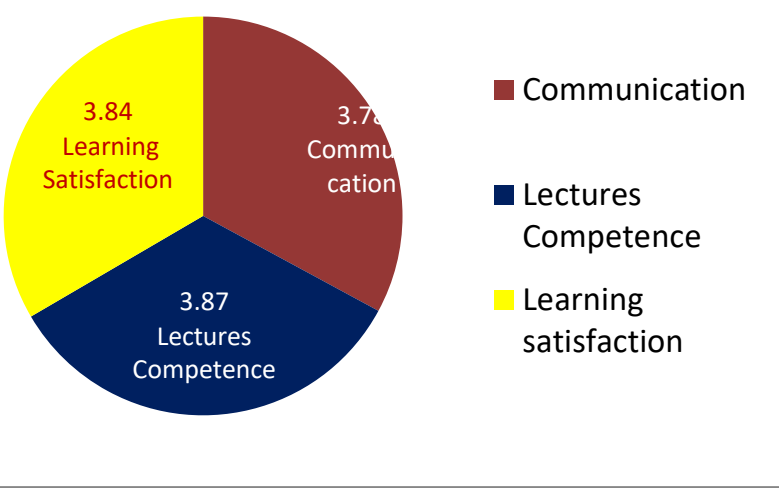

Figure 1. Respondents Majoring in Manajemen

Based on data obtained from questionnaires returned by respondents, the overall communication variable is 3.79. As for the Lecturer competency variable, it was 3.87. Learning satisfaction was 3.84. The total average of 3.85 is in the high category. 


\section{Respondents Majoring in Accounting}

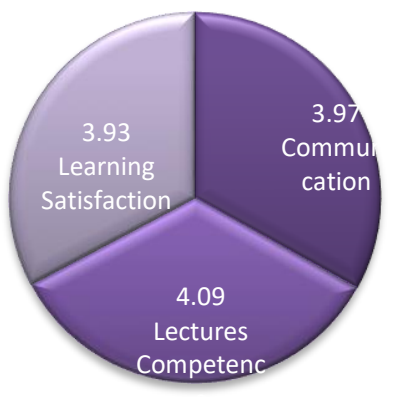

Communication

- Lectures

Competence

$\square$ Learning

Satisfaction
In the table above, it can be seen that the calculated $\mathrm{f}$ value is 52.578 while the $\mathrm{f}$ table is 2.642 , which means that the obtained $F$ count $>$ f table $(52.578>2.642$. Then it can also be seen from the p-value in the sig column of $0.000<0.05$. This shows that It is concluded that $\mathrm{H} 0$ is rejected and $\mathrm{H} 1$ is accepted. So simultaneously communication and lecturer competence have a significant effect on learning satisfaction.

Table 4. Test results $\mathrm{t}$ with Coefficients ${ }^{\mathrm{a}}$

\begin{tabular}{|c|c|c|c|c|c|}
\hline \multirow{2}{*}{ Model } & \multicolumn{2}{|c|}{$\begin{array}{c}\text { Unstandardized } \\
\text { Coefficients }\end{array}$} & \multirow{2}{*}{$\begin{array}{c}\begin{array}{c}\text { Standardized } \\
\text { Coefficients }\end{array} \\
\text { Beta }\end{array}$} & \multirow{2}{*}{$\mathrm{t}$} & \multirow{2}{*}{ Sig. } \\
\hline & B & $\begin{array}{l}\text { Std. } \\
\text { Error }\end{array}$ & & & \\
\hline (Constant) & 12.486 & 2.116 & & 5.893 & .000 \\
\hline Communication & .199 & .060 & .234 & 3.344 & .001 \\
\hline Competence & .271 & .063 & .302 & 4.273 & .000 \\
\hline
\end{tabular}

a. Dependent Variable: Learning Satisfaction

The communication variable has a t count of 3,344> $1,969 \mathrm{t}$ table, which means that the communication variable has a positive effect on the learning satisfaction variable. P-value of $0.001<0.05$ means that the communication variable has a significant effect on the learning satisfaction variable.

The lecturer competency variable has a t-count value of 4.273> $1.969 \mathrm{t}$ table, which means that the lecturer competence variable has a positive effect on the learning satisfaction variable. The P-value of 0.000 $<0.05$ means that the lecturer competence variable has a significant effect on the learning satisfaction variable.

\section{CONCLUSION}

Based on the results of research and discussion, the following conclusions can be drawn:

1) Communication variables effect positive and significant on student satisfaction variables of STIE Pembangunan Tanjungpinang.

The communication variable (X1) has a positive effect with a value of 0.199 on the learning satisfaction variable $(\mathrm{Y})$. This means that every 1 point increase in communication will increase learning satisfaction assuming other factors remain.

Lecturer competence variable (X2) has a positive effect with a value of 0.271 on the learning satisfaction variable (Y). This means that every 1 point increase in lecturer competence will increase learning satisfaction assuming other factors remain.

Table 3. Test results $\mathrm{F}$ and $\mathrm{ANOVA}^{\mathrm{a}}$

\begin{tabular}{|ll|r|r|r|r|r|}
\hline & Model & $\begin{array}{c}\text { Sum of } \\
\text { Squares }\end{array}$ & df & $\begin{array}{c}\text { Mean } \\
\text { Square }\end{array}$ & F & Sig. \\
\hline 1 & Regression & 1593.644 & 3 & 531.215 & 52.578 & .000 \\
& Residual & 2404.592 & 238 & 10.103 & & \\
& Total & 3998.236 & 241 & & & \\
\hline
\end{tabular}

2) Variables of competence has positive and significant influences on the variables of student satisfaction at STIE Pembangunan Tanjungpinang.

3) Communication variables and lecturer competence together have an effect on student learning satisfaction variables at STIE Pembangunan Tanjungpinang.

We proposed some suggestions as follow;

Judging from the results of the study, the variable that has the smallest effect is communication on learning satisfaction, meaning that students still assess the communication of lecturers as unsatisfactory, in order to create learning satisfaction for STIE Pembanguna Tanjungpinang students. this should be given special attention by the campus to 
further improve the quality of education at STIE Pembanguna Tanjungpinang.

The variable competence of lecturers is assessed from the results of research on the standard of competency of the STIE lecturers. Because the results of this study show that lecturer competence has the greatest influence on the effect of learning satisfaction, it is hoped that the competency standards of lecturers can be maintained and improved.

\section{REFERENCES}

[1] C. J. Bonk, "Online Teaching in an Online World (executive summary)," USDLA Journal, vol. 16, no. $1,2002$.

[2] Yi Shun Wang, Hsiu Yuan Wang, and Daniel Y. Shee, "Measuring e-learning systems success in an organizational context: Scale development and validation." Computers in Human Behavior, vol. 23, no. 4, pp. 1792-1808, 2007.

[3] M. Ali, S. M. K. Hossain, and T. Ahmed, "Effectiveness of E-learning for university students: evidence from Bangladesh," Asian Journal of Empirical Research., vol. 8, no. 10, pp. 352-360, 2018.

[4] Sumit Goyal, "E-Learning: Future of Education," Journal of Education and Learning., vol . 6, no. 2, pp. 239-242, 2012.

[5] O. O. Jethro, M. A. Grace, and K.A. Thomas, "Elearning and its effects on teaching and learning in a global age," International Journal of Academic Research in Business and Social Sciences., vol. 2 no. 1, pp. 203-210, 2012.

[6] T. A. Prasetya, and C. T. Harjanto, "Improving learning activities and learning outcomes using the discovery learning method," VANOS Journal of Mechanical Engineering Education., vol. 5, no. 1, pp. 59-66, 2020.

[7] Latip, A. (2020). The role of information and communication technology literacy in distance learning during the Covid-19 pandemic. EduTeach: Jurnal Edukasi danTeknologi Pembelajaran, 2),108-116. Doi https://doi.org/10.37859/eduteach. v1i2.1956

[8] Wibowo. (2013). Organizational culture. Depok. PT.Raja Grafindo Persada.

[9] Wibowo (2014). Behavior in Organizations. Jakarta: Rajawali Pers.

[10] Puspayani, Desak Nyoman. 2013. Contribution of Infrastructure, Administrative Services, Teacher
Professional Competence on Learning Satisfaction (Study of Student Perceptions of SMA Negeri 1 Sukawati).

http://ejournal.unigal.ac.id/html/index.php?idjurnal $=10 \&$ prodi_teng $=28 \&$ tengah_isi jurnal 